\title{
Critical Review on Development of Lean Construction in Indonesia
}

\author{
Hakas Prayuda ${ }^{1}$, Fanny Monika $^{1 *}$, Martyana Dwi Cahyati ${ }^{1}$, Hermansyah $^{2}$, Besty \\ Afriandini $^{3}$, Diky Budiman ${ }^{4}$ \\ ${ }^{1}$ Department of Civil Engineering, Faculty of Engineering, Universitas Muhammadiyah Yogyakarta, Indonesia \\ ${ }^{2}$ Department of Civil Engineering, Faculty of Engineering, Universitas Teknologi Sumbawa, Indonesia \\ ${ }^{3}$ Department of Civil Engineering, Faculty of Engineering, Universitas Muhammadiyah Purwokerto, Indonesia \\ ${ }^{4}$ Department of Architecture and Planning. Faculty of Science and Technology, Universitas Karimun, Indonesia \\ *Corresponding author. Email: fanny.monika.2007@ft.umy.ac.id
}

\begin{abstract}
Lean construction is one method that may reduce waste on construction projects. Waste is something that is non-value adding activities in the construction site. Implementing lean concepts into the construction industry is expected to increase the company's productivity. In this study, we have reviewed any causes that make much waste in the construction industry in Indonesia and how the effects of the application of lean construction to reduce waste in a construction site. The results show that there is much waste in construction projects. Some of the most common cases are design changes when the project is being implemented, workers who are still not qualified, complicated bureaucratic systems, and always late in making decisions, and materials always do not on time to the construction site. The above causes a work effect that is not following the plan, and the project becomes a delay from the schedule. Implementing the lean concept in construction companies shows that it takes a long time to change the mind-set and work culture in Indonesia. The lean concept is a strategic concept to be implemented in developing countries like Indonesia.
\end{abstract}

Keywords-Lean Construction, Developing Countries, Indonesia

\section{INTRODUCTION}

As a developing country, construction projects have become important priorities by the Indonesian government, where the Indonesian construction industry has ranked the third most important after the food and textile industries [1,2]. In the development of the Indonesian construction industry demands a change towards a more modern country. The productivity of the construction industry in Indonesia depends not only on workers who have the expertise but also on the quality of the material, good construction methods, and management in the field that is quite capable [3]. Many companies in Indonesia have implemented several concepts that can potentially increase productivity and quality, such as Total Quality Control (TQC), implementing ISO 9000 standards, and Total Quality Management (TQM) [4].

The productivity level of construction companies is influenced by the growth of the Gross Domestic Product, where this value continues to increase and has been predicted to increase by $8.31 \%$ in 2021 [5]. The development of the construction industry globally raises various problems that must be faced by each activist in the field of construction. Efforts to improve company management's competitiveness and quality are the company's big duty to remain competitive globally. The most problems in the construction industry in
Indonesia were industrial structure, business management capabilities, individual worker capacity, and business efficiency [6].

In addition to the above problems, according to Koskela [7], more than $30 \%$ of costs of construction are spent on nonvalue adding activities such as re-work, material handling, waiting for time, and movement of workers also overproduction. In many big cities in the world, Waste in construction projects is a major problem that is a concern for companies in the construction industry, especially in Indonesia. The delete activities method that is not needed in the construction process is to use the lean construction concept, where this method can also increase productivity so that the project becomes effective [8].

Implementing the lean construction concept in various countries is rather slow, although with this method the company will benefit a lot [9]. Although some companies have tried to adopt this concept, there seems to be an obstacle to implementing this concept. In Indonesia, Construction industries had not paid more attention to the lean construction concept in handling projects to reduce waste on resources [10]. So it needs further attention to how much this concept has been applied.

This study has explained the development of the lean construction implementation concepts in Indonesia, 
specifically for construction projects from the government (in this case, BUMN) and the private sector. Through this study, it is expected to find out how much the effect of the lean construction concept can be useful for the Indonesian construction industry and the obstacles faced during the process of applying lean construction management methods.

\section{LEAN CONSTRUCTION THEORY}

According to Koskela et al. [11], lean construction was introduced as a new construction management concept in the mid-1990s. Lean construction is a management concept that may increase productivity in the construction industry [12]. Lean construction was adopted from the lean production concept that was developed from the Toyota Company from Japan. The concept of lean construction always used the synonym word in the form of waste in the form of expenditure that does not produce value, some activities that absorb resources but do not produce value $[13,14]$. The goal of lean construction is to reduce or eliminate all waste in construction projects to become more productive with existing resources.

The main difference between traditional manufacturing and lean manufacturing is in the control method, optimization of performance, Scheduling method, production system, and customer satisfaction [12]. The most basic difference between the lean concept and traditional concept is found in the work scheduling method. Table I describes the differences between lean and traditional concepts. Some of the advantages of implementing lean construction concepts include shorter construction periods, productivity gains, more satisfied clients, greater predictability, improved health and safety, improved design, and improved quality with fewer defects [15].

Table I. The Different between Traditional and Lean Concept [12]

\begin{tabular}{|l|l|l|}
\hline \multicolumn{1}{|c|}{ Item } & \multicolumn{1}{|c|}{ Traditional } & \multicolumn{1}{c|}{ Lean } \\
\hline Control & Tracking & Steering \\
\hline Scheduling Method & Push Work Schedule & Pull Work Schedule \\
\hline Production System & Conversion Production System & Flow Production System \\
\hline Production Process & Efficiency & Effectiveness \\
\hline Planning & Knowing & Learning \\
\hline Coordination & Following Orders & Keeping a Promise \\
\hline Optimization & A Specific Activity & The Entire Project \\
\hline Performance Measurement & CPM, Earned Value, WBS & Percent Plan Complete (PPC) \\
\hline Customer Satisfaction & The owner or Final Consumer Satisfaction & Successor Process Satisfaction \\
\hline Goal of Supervision & Point Speed \& Productivity & Reduce Variation \& Manage Flow \\
\hline Uncertainty & External & Internal \\
\hline
\end{tabular}

Table II. Lean Implementation Tool [20]

\begin{tabular}{|c|c|c|c|}
\hline Scope & Technique & Requirements & Criteria/Change \\
\hline \multirow{6}{*}{ Flow Variability } & \multirow{6}{*}{ Last Planner } & Reverse Phase & Pull Approach \\
\hline & & Scheduling & Quality \\
\hline & & Six Week Look Ahead & Knowledge \\
\hline & & Reasons for Variance & Communication \\
\hline & & PPC Charts & Relation with Other Tools \\
\hline & & Weekly Work Plan & \\
\hline \multirow{5}{*}{ Process Variability } & \multirow{5}{*}{ Fail-Safe for Quality } & Check for Quality & Actions on the Job Site \\
\hline & & Check for Safety & Team Effort \\
\hline & & & Communication \\
\hline & & & Knowledge \\
\hline & & & Relation with Other Tools \\
\hline \multirow{10}{*}{ Transparency } & \multirow{5}{*}{ Increased Visualization } & Commitment Charts & Visualization \\
\hline & & Mobile Signs & Team Effort \\
\hline & & Safety Signs & Communication \\
\hline & & Project Milestones & Team Effort \\
\hline & & PPC Charts & Relation with Other Tools \\
\hline & \multirow{5}{*}{ Five S's } & Sort & Actions on the Job Site \\
\hline & & Straighten & Team Effort \\
\hline & & Standardize & Communication \\
\hline & & Shine & Relation with Other Tools \\
\hline & & Sustain & Knowledge \\
\hline \multirow{3}{*}{ Continuous Improvement } & \multirow{3}{*}{ Huddle Meetings } & All Foreman Meeting & Time Spent \\
\hline & & Start of The Day Meeting & Review Work to be Done \\
\hline & & & Issues Covered \\
\hline
\end{tabular}




\begin{tabular}{|c|c|c|c|}
\hline Scope & Technique & Requirements & Criteria/Change \\
\hline \multirow{4}{*}{ First-Run Studies } & & Relation with Other Tools \\
\cline { 2 - 4 } & & Plan & Actions on the Job Site \\
\cline { 2 - 3 } & & Do & Team Effort \\
\cline { 3 - 4 } & & Check & Knowledge \\
\cline { 2 - 3 } & & Act & Communication \\
\cline { 2 - 4 } & & & Relation with Other Tools \\
\hline
\end{tabular}

One example of how to implement lean construction is to combine workers' capacity with organizational techniques so that they get high income with few resources [16]. Lean manufacturing concepts at the Toyota Production System (TPS) using four main elements, namely just in time (JIT), creative thinking, flexible workforce, and autonomation [17]. These four elements are believed to be a combination method that will get consistent results to reduce expenses, quality assurance, and still care about humanity. The concept used in just-in-time is that all inventory that is not valuable is not needed; inventory is only used when needed and produces profits. There are three methods for applying just-in-time concepts: using the Kanban system to minimize unused inventory, ensuring that the products produced can be fulfilled in the right order and demand, and reduce the set-up process can reduce production time [18, 19].

Applying lean construction requires four frameworks: process variability, transparency, flow variability, and continuous improvement [20,21]. Table II describes the tools that must be used and good techniques for starting to implement lean construction. Flow Variability (Heijunka) greatly affects the production level. This impact is used as a tool to control and optimize the products produced. Lean construction is focused on preventing defects, so it is very concerned about process variability. With traditional methods, defects cannot be known before construction is built so that with lean, this concept can prevent various kinds of defects that may occur.

In lean construction, every resource that does not contribute to improving performance must be eliminated immediately. In the process of elimination, this requires a high level of transparency. The ways to identify using the five $\mathrm{S}$ method are standardized (seixo), sustainable (shisuke), straighten (seition), Shine (seiketsu) also sort (seiri) [20, 21]. Meanwhile, continuous improvement (kaizen) cannot be connected with a special method because all methods must have good long-term continuity.

In developing and developed countries, many have applied lean construction to obtain good results in producing buildings. Lean construction is a good enough strategy to be applied to the construction industry in Sri Lanka. Besides being more comfortable, this method is easily accepted in the country [22]. On another occasion, lean construction can significantly increase productivity in construction projects because all construction processes are easier to predict and can minimize everything that is not important [23,24]. This method is strongly recommended to be included in the college curriculum so that every student has a good basis for producing more productive.

The causes of the many construction wastes in developing countries are Malaysia. The results obtained stated that poor management in the field and supervision system, lack of planning and scheduling, caused many errors and errors during the construction process [25]. Through these studies, it is suggested that apply various concepts that can improve the construction industry's level of effectiveness and productivity so that this study will review how the effects are not developments from Lean Construction in Indonesia.

\section{RESEARCH METHODOLOGY}

Some literature reviews on the concepts have carried out advantages of lean construction and critical reviews of lean project management [26, 27]. While the critical review of lean construction to reduce production costs in complex projects has been carried out [28]. In this study, we will summarize the research that has been done on the implementation of lean concepts in construction projects in Indonesia. The method used from this study consists of several stages, from the first stage to be carried out by searching the literature as much as possible about the concept of lean construction until the analysis of the data obtained so that conclusions can be drawn.

In the first stage, the research material search has been done on implementing lean construction in Indonesia construction company. This search has used the title, abstract, or keyword of the previous researcher in writing his scientific work. The keywords used in this search are lean construction, six sigma, lean manufacturing, waste in construction, and several other keywords. The search area is limited to construction management and industrial engineering, especially regarding logistics and supply chains. The publication results are classified into several parts, consisting of reputable international journals, non-reputable international journals, international conferences, and national seminars. In this study, the results of national-level publications are still used because not many previous researchers have published the results of their research into international journals and international conferences.

After the tracking journal is completed, it is continued with the review phase of each existing journal. At this stage, have studied the purpose of the research, the method used, and the results. Through this stage, it is expected to meet weaknesses that cause good or not the process of researching to affect the results obtained. Reporting is done after all conclusions can be drawn according to the goals to be achieved.

\section{RESULTS AND DISCUSSION}

\subsection{Company Profile}

Before carrying out a deeper analysis of the lean concept's 
implementation in the construction industry, in Table I, general construction work is carried out in Indonesia. Private projects in Indonesia are still dominated by high-rise buildings, 56\% [29], and 44\% [30]. In comparison, the rest consists of residential and housing, infrastructure, and various other types of construction, such as factories, supermarkets, and sports centers. Based on the study results, there were no significant differences regarding the composition of construction work in Indonesia, only in residential development, which showed a sizeable comparison in 2003 of only $3 \%$ and increased to $22 \%$ in 2009.

According to Alwi et al. [31], as many as 52\% of companies have ISO 9000 accreditation, $37 \%$ say they have never applied and enrolled in ISO 9000 accreditation. The remaining 5\% are applying for ISO accreditation, and 7\% have quality control and system with a different method. Fig. 1 (b) describes several variations of the types of companies that control Indonesia's market. 32\% of companies surveyed belong to the Indonesian government, while $56 \%$ are private companies. While the remaining $10 \%$ is a Joint Venture and $2 \%$ are other types of companies involved in the construction industry. Through these two images, it can be concluded that more than half of the companies evaluated have had accreditation and followed the applicable management standards.

Most companies that have implemented the ISO standard are 2 to 6 years old, with 4 years. However, has implemented management that has been made by companies ranging from three to 10 years. The development of the construction industry in Indonesia had developed quite rapidly [32]. In 2013, it was reported that Indonesia had a construction business entity of 131080 so that the Indonesian construction market was one of the largest in Southeast Asia. Besides, there are also construction industries from several countries in Indonesia. In 2013, it was reported that 81 construction companies in Indonesia were from Japan, 53 from China, 81 from Korea, and 4 from India.

Table III. Project Construction Category

\begin{tabular}{|c|c|c|}
\hline Construction type & $\begin{array}{c}\text { Alwi et al. } \\
{[29]}\end{array}$ & $\begin{array}{c}\text { Larasati and } \\
\text { Tsunemi [30] }\end{array}$ \\
\hline Building Construction & $56 \%$ & $44 \%$ \\
\hline Residential & $3 \%$ & $22 \%$ \\
\hline Infrastructures & $19 \%$ & $16 \%$ \\
\hline Other Construction & $21 \%$ & $18 \%$ \\
\hline
\end{tabular}

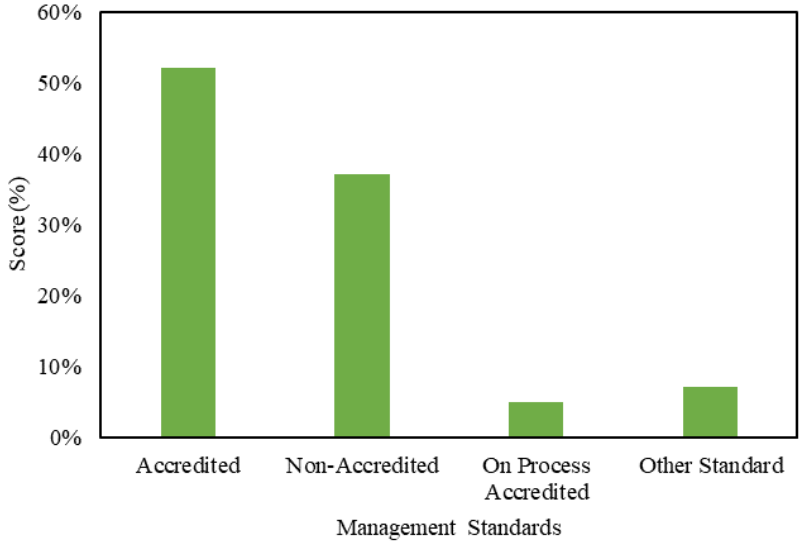

Fig 1. Application of ISO Standards on Construction Company in Indonesia [31]

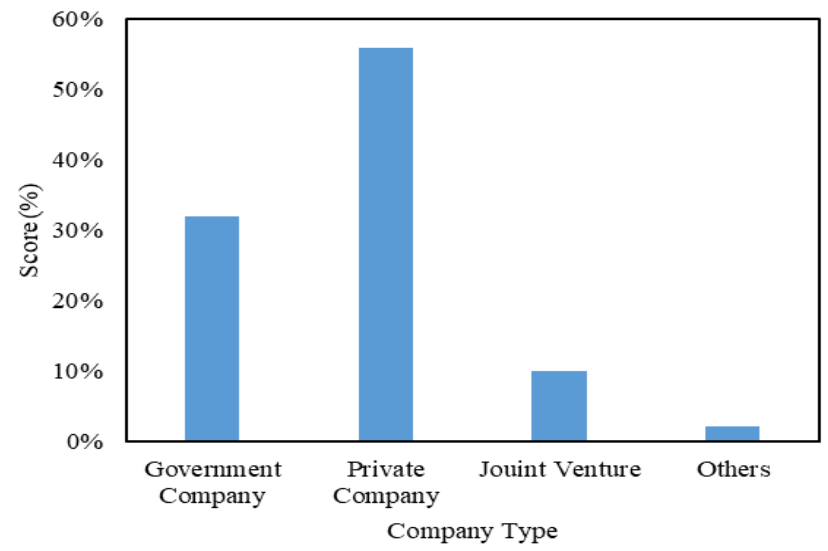

Fig 2. Types of Companies in Indonesia [31]

\subsection{Waste Causes Variables}

Applying lean concepts in the construction industry should identify what variables can cause inefficiencies in construction projects. Alwi et al. [32] sort categories from waste into five parts, namely repair, waiting periods, material, human resource, and operation. Each section has several important points, which are often the cause of ineffective construction project work.

Based on Alwi et al. [29] explained that the construction process's level of performance in Indonesia is still very low, which the cause of a high level of waste is. This waste is caused by several factors such as the turnover of the final project, the waiting time for material arrival to the project location, the delay in working time, which is not following the schedule, waste of raw materials on the construction site, and low level of accuracy in the supervision process. In conclusion, the variables that cause irregularities in the construction system in Indonesia are design changes, always late in decision making, lack of skills of workers and managers, frequent errors in selecting construction methods, and poor coordination between project components, causing the material to arrive late, not good in planning and scheduling.

The causes of inefficient construction work in Indonesia. The basis of lean principles starts with the Toyota Way 
Concept [33]. Based on the study, it was found that workers and companies are not familiar with this concept and how the system works. Weaknesses are caused by workers' lack of focus in the development process so that it can be concluded that implementing the lean construction concept will require extra funds at the beginning so that the process of this change needs to be done from small groups in the company. Some causes of poor performance and generating much waste in constituent projects are financial factors, too many partners in project work, unfair competition among workers, always late in making decisions, and poor management systems that apply. However, it is still very possible to apply lean concepts in Indonesia, but it only takes longer to get good results.

Too much waiting for the cause of much waste in construction projects from various parties participating in the project [34]. Besides that, the cause of much waste is a sudden design change or an additional user project. The lack of clarity of management and material suppliers' database is one of the causes of delays in the construction process. Besides, workers' level of error is still quite high, especially using equipment that requires expertise, while workers do not have expertise in that field.

Sugiantari et al. [35] identified waste in construction projects in the process of implementing lean construction. Through this research, the results showed that there were seven main causes of waste in construction projects: lack of inspection activities by supervisors because workers lacked expertise, unclear supplier databases, resulting in material quality not according to specifications. The delay in decisionmaking is one of the causes of the delay in working on the project. Another factor is always late in sending construction materials, the management process that uses a complicated bureaucratic system, unclear information from the owner, and the poor communication system used between partitions in the development process cause much waste.

Based on some of the explanations above, it can be concluded what the causes of many wastes in construction projects in Indonesia are. The main cause of waste is due to design changes that always occur when the construction process is in progress, scheduling that does not take into account various things that can occur, poor worker expertise and poor supervision, and a complicated bureaucratic system that causes slow decision making, and difficult in the process of communication between divisions.

\subsection{Implementation of Lean Construction}

After knowing the causes of waste on construction projects, further discussion of the implementation of the Lean concept in constricting projects in Indonesia, Sugiantari et al. [35] concluded that lean construction has the potential to be implemented in Indonesia because it can reduce waste that is not of value-added so that applying this concept can be an additional advantage in construction projects. On the other hand, it was found that the kaizen mentality of construction workers in Indonesia was still not good, so it would be more difficult to implement lean construction. Continuous improvement needs to be done and requires a long time. Profit is a top priority of construction companies in Indonesia.
The application of lean construction obtained quite good results in several construction companies in Indonesia because companies that had implemented lean construction had excellent achievements [34]. However, control must be carried out and the improvement is mainly on changes in worker culture, system management, and the functions of each team that has been previously formed. Some companies that have implemented lean construction for quite a long time, more than 10 years, obtain substantial profits and compete with foreign companies working in Indonesia.

A study by implementing just-in-time concepts in several construction companies in Indonesia [36]. The method used is by training companies so that they can improve construction productivity and increase competitiveness. The training was carried out in moral enhancement, increased skills, abilities, and hence productivity. The results showed that it succeeded in reducing fluctuations from a complete percent plan with this training and increasing the stable value. Through this training, it can be concluded that it has the potential to increase the productivity of workers' performance.

Research and implementation of lean construction in Indonesia are still very little done. Although this concept has been introduced for a long time, the difficulties encountered are not easy to change workers' culture, so that it takes a long time to implement this method. This method is strategic for developing countries like Indonesia. With the amount of waste produced but does not produce benefit, there will be a continuous waste on construction projects.

The many constraints that must be in implementing lean construction will certainly make the company need more funds like the training process to change workers' mindset and culture. At present, most construction companies in Indonesia still prioritize profit so that when implementing lean construction, it is very likely to reduce company profits at first. So the mindset must also be changed by prioritizing quality and good management processes to get better results in the future.

\section{CONCLUSION}

Based on the results and discuss some conclusions were drawn. Many factors have resulted in waste on construction projects. The main factors produced as causes of waste are the lack of workers' ability, design changes during the construction process, slow decision-making, and complicated bureaucratic systems.

Some companies that have implemented lean construction obtain good results and can compete globally. However, it takes a long time to obtain these results, this is due to the process of changing work culture and mindset that cannot be changed directly.

Implementing lean construction in Indonesia is strategic and has the potential to increase productivity in construction projects. However, there will be a significant amount of funds initially because there are still many workers who are not familiar with this system. 


\section{REFERENCES}

[1] Alwi, S., Hampson, K., and Mohamed, S. Waste in the Indonesian Construction Project. Proceedings of the 1st International Conferences of CIB W107 - Creating a Sustainable Construction Industry in Developing Countries. 11-13 November 2002. South Africa. Pp 305-315. 2002.

[2] Royat, S. Development Strategy of the Construction Industry in Indonesia. Workshop on Strategic Management in Construction Industry. Bandung. Indonesia. 1994.

[3] Arditi, D., and Mochtar, K. Trends in Productivity Improvement in the US Construction Industry. Journal of Construction Management and Economic. 18. Pp. 15-27. 2000.

[4] Alwi, S. Factor Influencing Construction Productivity in The Indonesian Context. Proceedings The 5th EASTS Conference. Fukuoka. Japan. 2003.

[5] Sparta. Risiko Kredit dan Efisiensi Perbankan Indonesia. MIX: Jurnal Ilmiah Manajemen. 6(1). Pp. 28-44. 2016.

[6] Veronika, A., Riantini, L. S., and Firmansyah. B. A. Identification of The Factors in Corporate Management that Influence Construction Company's Performance in Indonesia. Innovation in Structural Engineering and Construction. Pp. 1363-1367. 2008.

[7] Koskela, L. J. An Exploration Towards a Production Theory and its Application to Construction. Doctor of Philosophy on Technology. Helsinki University of Technology. Finland. 2000.

[8] Abdullah, S., Razak, A. A., Abubakar, A., and Mohammad, I. S. Towards Producing Best Practice in the Malaysian Construction Industry: The Barriers in Implementing the Lean Construction Approach. Proceedings of The International Conference on Construction Industry. Padang. Indonesia. 2009.

[9] Johansen, E., and Walter, L. Lean Construction: Prospects for the German Construction Industry. Lean Construction Journal. 3. Pp. 19-32. 2007.

[10] Herliandre, A., and Suryani, F. Penerapan Konstruksi Ramping (Lean Construction) Pada Pembangunan Gedung di Bintaro. Jurnal Ikra-Ith Teknologi. 2(3). Pp. 34-41. 2018.

[11] Koskela, L. J., Tommelein, I., and Ballard, G. The Foundation of Lean Construction. The University of Huddersfield. Finland. 2002.

[12] Kim, D., and Park, H. S. Innovative Construction Management Method: Assessment of Lean Construction Implementation. KSCE Journal of Civil Engineering. 10(6). Pp. 381-388. 2006.

[13] Buzby, C. M., Gerstenfeild, A., Voss, L. E., and Zeng, A. Z. Using Lean Principles to Streamline the Quotation Process: a Case Study. Industrial Management and Data Systems. 102(9). Pp. 513-520. 2002.

[14] Womack, J. P., and Jones, D. T. Lean Thinking: Banish Waste and Create Wealth in Your Corporation. Simon and Schuster. New York. The United States. 1996.

[15] Mossman, A. Why isn't the UK Construction Industry Going Lean With Gusto?. Lean Construction Journal. 5(1). Pp. 24-36. 2009.

[16] Katayama, H. Lean Production in a Changing Competitive World: A Japanese Perspective. International Journal of Operation Production Management. 16(2). Pp. 8-23. 1996.

[17] Monden, Y. Toyota Production System: Practical Approach to Production Management. Industrial Engineering and Management Press. The University of Michigan, United States. 1983.

[18] Chaoiya, C., Liberopoulos, G., and Dallery, Y. The Extended Kanban Control System for Production Coordinating for Assembly Manufacturing Systems. IIE Transactions. 32(10). Pp. 999-1012. 2000.

[19] Miltenburg, J. Balancing and Scheduling Mixed-Model UShaped Production Lines. International Journal of Flexible Manufacturing Systems. 14(2). Pp. 119-151. 2002.
[20] Salem, O., Solomon, J., Genaidy, A., and Minkarah, I. Lean Construction: From Theory to Implementation. Journal of Management in Engineering. 22(4). Pp. 168-175. 2006.

[21] Santos, A. D. Application of Flow Principles in The Production Management of Construction Sites. Ph.D. Thesis. The University of Salford. The United Kingdom. 1999.

[22] Senaratne, S., and Wijesiri, D. Lean Construction as a Strategic Option: Testing it's Suitable and Acceptability in Sri Lanka. Lean Construction Journal. Pp. 34-38. 2018.

[23] Adegbembo, T. F., Bamisaye, O. P., and Aghimien, D. O. Assessment of Lean Construction Practice in the Nigerian Construction Industry. Proceedings of the Joint International Conference (JIT) on 21st Century Human Habitat: Issues, Sustainability and Development. Akure. Nigeria. Pp. 756-764. 2016.

[24] Ahiakwo, O., Oloke, D., Suresh, S., and Khatib, J. Critical Review of Potential for Implementation of Lean in the Nigerian Building Industry. Proceedings of the 20th Annual Conference of the International Group for Lean Construction. California. The United States. 2012.

[25] Nagapan, S., Rahman, I. A., Asmi, A., Memon, A. H., and Zin, R. M. Identifying Causes of Construction Waste - Case of Central Region of Peninsula Malaysia. International Journal of Integrated Engineering. 4(2). Pp. 22-28. 2012.

[26] Garrido, J. S., Pasquire, C., and Thorpe, T. Critical Review of the Concept of Value in Lean Construction Theory. 18th Annual Conference International Group for Lean Construction. Israel. Pp. 1-9. 2010.

[27] Alhalafi, M. D. M., and Kang, P. S. A Critical Review of Lean Project Management and Its Application in Construction Project Management. International Journal of Scientific and Engineering Research. 8(6). Pp. 1137-1142. 2017

[28] Wong, L. S., and Ahmed, M. E. A. M. A Critical Review of Lean Construction for Cost Reduction in Complex Projects. Jordan Journal of Civil Engineering. 12(4). Pp. 707-720. 2018.

[29] Alwi, S., Hampson, K., and Mohamed, S. Non-Value-Adding Activities: A Comparative Study of Indonesian and Australian Construction Project. Proceedings 10th of The International Group of Lean Construction Conference. Brazil. Pp. 627-638. 2002.

[30] Larasati, D., and Tsunemi, W. Evaluation Study on Existing Condition of Indonesian Construction Industry: How to Improve Performance and Competitiveness. Society for Social Management Systems Internet Journal. 5(1). Pp. 1-11. 2009.

[31] Alwi, S., Hampson, K., and Mohamed, S. Factors Influencing Contractor Performance in Indonesia: A Study of Non-ValueAdding Activities. Proceedings International Conference on Advancement in Design Construction, Construction Management and Maintenance of Building Structure. Indonesia. Pp. 20-34. 2002.

[32] Sukandar, B. M., Achsani, N. A., Sembel, R., and Sartono, B. Efisiensi Perusahaan Konstruksi di Indonesia. MIX: Jurnal Ilmiah Manajemen. 8(3). Pp. 628-639. 2018.

[33] Wijaya, M. R. A., Hatmoko, J. U. D., and Suripin. Assessment of Lean Construction Principles: A Case Study at Semarang Medical Centre Hospital Project. Jurnal Media Komunikasi Teknik Sipil. 21(2). Pp. 91-100. 2015.

[34] Karningsih, P. D., Anggrahini, D., Karim, M. B., and Adhitama, R. Improving Project Efficiency using Lean Construction. International Conference on Advanced Mechatronic, Intelligent Manufacture, and Industrial Automation. Pp. 334-336. 2017.

[35] Sugiantari, S., Putera, I. G. A. A., and Diputra G. A. Aplikasi Lean Construction untuk Mengidentifikasi Pemborosan oada Proses Logistik Proyek. Jurnal Spektran. 3(2). Pp. 1-9. 2016.

[36] Alwi, S., Kajewski, S., and Hampson, K. The investigation into The Relationship Between Just in Time (JIT) Training and Productivity in Building Construction in Indonesia. 1st International Construction Specialty Conference. Canada. Pp. 1-7. 2006 